\title{
Bt Brinjal in Bangladesh: The First Genetically Engineered Food Crop in a Developing Country
}

\author{
Anthony M. Shelton, ${ }^{1}$ Md. J. Hossain, ${ }^{2}$ Vijay Paranjape, ${ }^{3}$ Md. Z.H. Prodhan, ${ }^{4}$ Abul K. Azad, ${ }^{4}$ \\ Rituparna Majumder, ${ }^{3}$ Sayed H. Sarwer, ${ }^{2}$ and Md. A. Hossain ${ }^{2}$ \\ ${ }^{1}$ Department of Entomology, Cornell/NYSAES, Geneva, New York, 14456, USA \\ ${ }^{2}$ Feed the Future South Asia Eggplant Improvement Partnership, Ithaca, New York 14853, USA \\ ${ }^{3}$ Sathguru Management Consultants Private Limited, Banjara Hills, Hyderabad 500034, India \\ ${ }^{4}$ Bangladesh Agricultural Research Institute, Gazipur 1701, Bangladesh \\ Correspondence: ams5@cornell.edu
}

Eggplant, or brinjal (Solanum melongena), is a popularly consumed vegetable grown throughout Asia that is prone to vicious and sustained attack by the eggplant fruit and shoot borer (EFSB) (Leucinodes orbonalis) throughout the growing season. Yield losses in Bangladesh because of EFSB infestation have been reported as high as $86 \%$. Farmers reduce crop losses by frequent applications of insecticide. To counter the EFSB pest, Bangladesh has developed and released four Bt brinjal varieties expressing Cry $1 \mathrm{Ac}$ (Bt brinjal). Bangladesh is the first developing country to release a commercial genetically engineered (GE) food crop. In this article, we discuss the development and adoption of Bt brinjal in Bangladesh from initial distribution to 20 farmers in 2014 to cultivation by more than 27,000 farmers in 2018. Bt brinjal provides essentially complete control of EFSB, dramatically reduces insecticide sprays, provides a sixfold increase in grower profit, and does not affect nontarget arthropod biodiversity. A major focus is to ensure its durability through stewardship. Bangladesh has shown great leadership in adopting biotechnology for the benefit of its farmers and serves as an example for other countries.

\section{HISTORY OF Bt CROPS}

$\mathrm{O}_{\mathrm{s}}^{\mathrm{n}}$ ne of the earliest published reports of a genetically engineered (GE) plant expressing insecticidal crystal (Cry) proteins from the bacterium, Bacillus thuringiensis (Bt), was by Monsanto scientists who transformed the tomato in 1987 (Fischhoff et al. 1987). Their report was prescient when the authors wrote, "These engineered tomato plants represent a significant step to increased selectivity, specificity and effi- cacy in insect control." In fact, Bt plants have revolutionized insect pest management in corn and cotton worldwide (Shelton et al. 2002; Romeis et al. 2008) by effectively controlling key insect pests while conserving their natural enemies (Romeis et al. 2019). However, perhaps the authors could not fully anticipate the extent of the social and political activism that their new technology would cause.

From an agronomic standpoint, Bt crops should be considered another form of a pest-

Editor: Pamela C. Ronald

Additional Perspectives on Engineering Plants for Agriculture available at www.cshperspectives.org

Copyright (C) 2019 Cold Spring Harbor Laboratory Press; all rights reserved; doi: 10.1101/cshperspect.a034678

Cite this article as Cold Spring Harb Perspect Biol 2019;11:a034678 
A.M. Shelton et al.

resistant crop (Kennedy 2008). They share the same potential benefits (e.g., reduced need for insecticides) and liabilities (e.g., insects developing resistance to the $\mathrm{Bt}$ proteins they express) as conventionally bred crops with host-plantresistant characteristics. There is a long history of conventional breeding to develop crops resistant to insect pests and much of this work continues to this day. Breeding for insect resistance has been especially successful in the case of field crops (e.g., wheat lines resistant to the Hessian fly and alfalfa lines resistant to the soybean aphid) and many of the genes have been identified (Smith and Clement 2012). However, there has been little success in developing resistant lines to insect pests in the orders of Lepidoptera (caterpillars) and Coleoptera (beetles); these two orders contain many of the world's most damaging pests.

Host plant resistance is considered a cornerstone of integrated pest management (IPM) because it provides an effective and economic way by which crop damage can be avoided (Stern et al. 1959; Naranjo and Ellsworth 2009). Bt crops are the first of what can be considered GE insect-protected crops, but they will certainly not be the last.

$\mathrm{Bt}$ is a family of bacteria that contains insecticidal proteins that, when ingested by certain insects, cause holes in their midgut that disrupt its function and lead to their death (Heckel 2012). Bt has been used as a foliar insecticide for decades and, although it had relatively limited use, it has a stellar safety record for humans and the environment (Shelton et al. 2002). Bt has critical limitations when used as a foliarly applied insecticide. First, its short persistence (2-4 days) may lead to frequent applications, which costs the farmer not only money for the product but also for its application. Second, because it needs to be ingested by the targeted insect, thorough coverage of plant parts is required. Such coverage is extremely difficult to obtain in many crops, especially those in which the insect bores into tissues, such as the European corn borer that bores into the stalk as well as into the ear. These limitations were overcome when the genes producing the Cry proteins were introduced into plants and the proteins were expressed in insect-susceptible plant parts.

The first GE crop to be commercialized anywhere was in 1995 using potato cultivars expressing the Bacillus thuringiensis var tenebrionis Cry 3A toxin against the Colorado potato beetle (CPB), Leptinotarsa decem lineata (Say) (cv NewLeaf, Monsanto). Bt potato controlled $\mathrm{CPB}$ very well even under intense pressure. However, Nature Mark, which marketed the product for Monsanto, dissolved after the 2001 season (Shelton 2012). The product was doomed because of several factors, most notably the controversy about a GE food crop. Such controversy continues for other fresh food crops. Meanwhile, Bt cotton and maize have been far more successful. In 2017, 59.7 million hectares of Bt maize and 24.1 million hectares of Bt cotton were grown globally (James 2018).

Bt crops have revolutionized insect pest management by providing host plant resistance to key pests in the insect orders, Lepidoptera and Coleoptera. Prior to the development of $\mathrm{Bt}$ crops, there were few examples of strong host plant resistance to these insect orders. For decades, Bt had limited use as a foliar insecticide primarily for organic growers, who had limited alternatives, and for arboreal pests where ecological sensitivity was critical. However, when insecticidal genes were incorporated into Bt crops, Bt quickly became a major insecticide. The adoption rates for $\mathrm{Bt}$ crops have been unprecedented in agriculture (James 2000). Between 1996 and 2015, this adoption has been associated with increases in farm income of more than $\$ 50,274 \mathrm{M}$ and $\$ 45,958 \mathrm{M}$ in $\mathrm{Bt}$ cotton and maize, respectively, and reductions of more than $268 \mathrm{M}$ and $87 \mathrm{M} \mathrm{kg}$ of insecticide-active ingredient in Bt cotton and maize, respectively (Brookes and Barfoot 2017). However, the potential benefits provided by $\mathrm{Bt}$ crops have largely gone unrealized in fruits and vegetables where insect management continues to rely primarily on the use of synthetic insecticides. Except for the use of Bt sweet corn, which has provided excellent control of ear-infesting caterpillars (Shelton et al. 2013), currently no Bt vegetables or fruits are commercialized. This is changing in at least one country of Southeast 
Asia-Bangladesh-with its 2014 release of Bt eggplant.

\section{EGGPLANT IN SOUTHEAST ASIA}

Solanum melongena L. (eggplant, also known as brinjal in India and Bangladesh, and talong in the Philippines) is one of the most important, inexpensive, and popular vegetable crops grown and consumed in Asia. Although its popularity varies by country in Asia, it is generally considered as one of the top five vegetables in Asia. The biggest constraint to eggplant production throughout Asia is a chronic and widespread infestation by the eggplant fruit and shoot borer (EFSB), Leucinodes orbonalis (Guenée) (Ali et al. 1980). Caterpillars damage eggplant by boring into the petiole and midrib of leaves and tender shoots, resulting in wilting and desiccation of stems. Larvae also feed on flowers, which results in flower drop or misshapen fruits. The most serious economic damage caused by EFSB is to the fruit, because the holes, feeding tunnels, and frass (larval excrement) make the fruit unmarketable and unfit for human consumption (Fig. 1). To control this insect, farmers routinely spray broad-spectrum insecticides, often 2-3 times per week, and, in some cases, twice a day (for an example of commonly used insecticides, see Del Prado-Lu 2015). Consequently, it is not uncommon to apply over 100 sprays per season, resulting in high residues on marketable fruit. Such an insecticide-dependent strategy poses both environmental and health concerns.

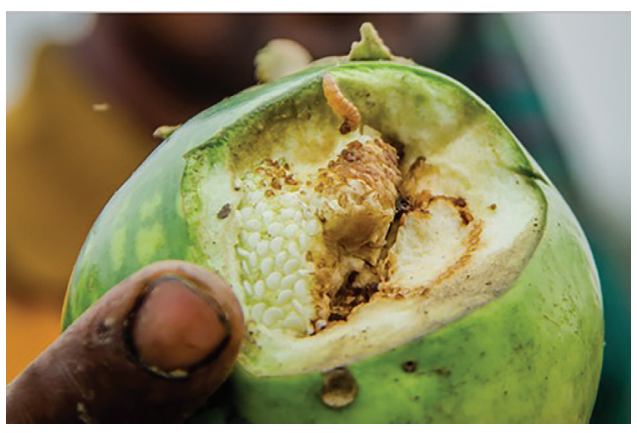

Figure 1. Eggplant fruit and shoot borer damage in non-Bt brinjal. (Photograph from the personal collection of Md. Arif Hossain.)

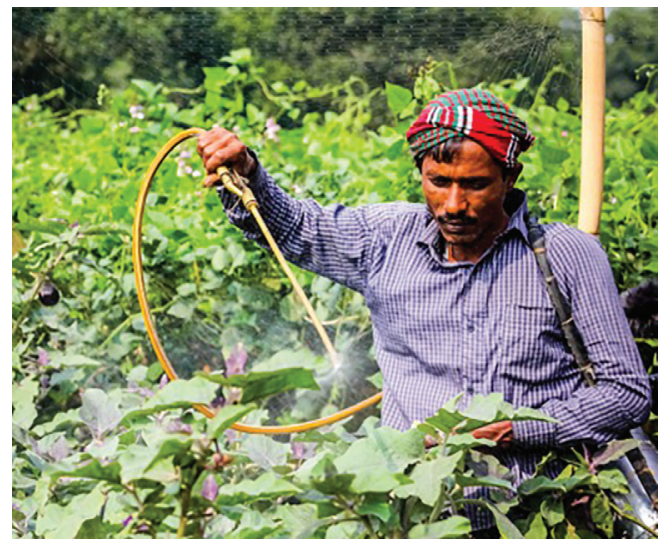

Figure 2. Bangladeshi farmer spraying an insecticide in non-Bt brinjal crop. (Photograph from the personal collection of Md. Arif Hossain.)

Environmental concerns include killing natural enemies that can help reduce pest populations, leaching of active pesticide ingredients into the soil and water, and harming pollinators. Health concerns include being a hazard to the applicator and farm workers, as well as to the consumer from high pesticide residues on the fruit. Typically, those who spray the crop are not aware of the hazards of pesticides and do not use any personal protective equipment (Fig. 2). These problems have been well documented in Bangladesh and other countries (bteggplant.cornell. edu/content/facts; bic.searca.org; Del Prado-Lu 2015). In addition to environmental and health concerns, populations of EFSB have also developed resistance to many foliar insecticides (Shirale et al. 2017).

\section{EGGPLANT IN BANGLADESH}

Bangladesh is a country of $147,570 \mathrm{~km}^{2}$ with a population of more than 165 million (Fig. 3). Vegetables are an important component of the Bangladeshi diet and more than 90 vegetables are cultivated. In terms of area and overall production, eggplant (brinjal) is the second-mostimportant vegetable grown by an estimated 150,000 resource-poor farmers on 51,000 ha throughout Bangladesh. Brinjal constitutes about $14.9 \%$ of winter vegetable production 
A.M. Shelton et al.

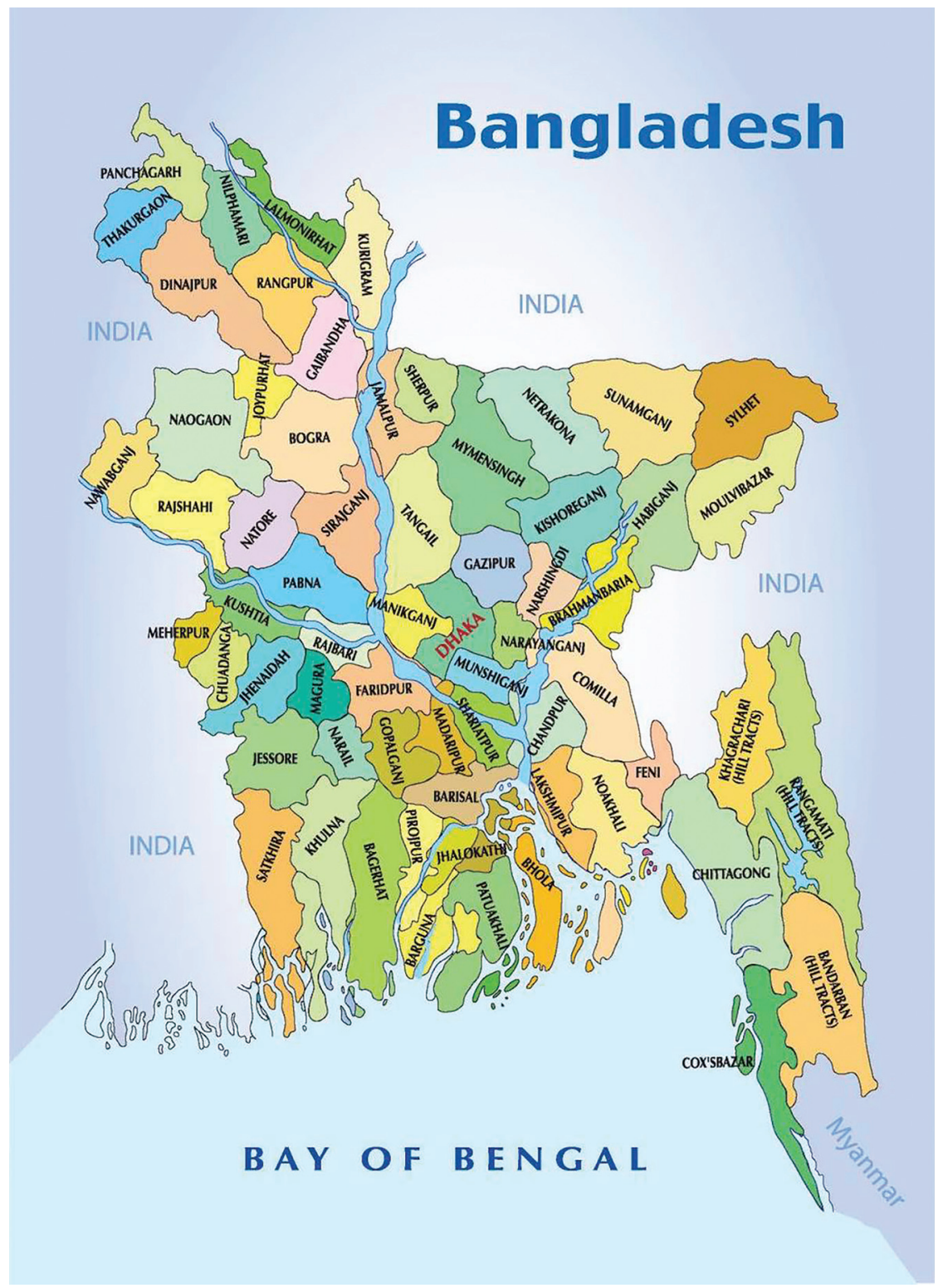

Figure 3. Map of Bangladesh. (Figure reprinted courtesy of childrenrights24@blogspot.com.)

and $9.7 \%$ of summer production (Bangladesh Bureau of Statistics 2018).

\section{DEVELOPMENT OF Bt EGGPLANT}

As an alternative to intensive use of insecticides, the India-based Maharashtra Hybrid Seed Company (Mahyco) inserted the crylAc gene, under the control of the constitutive $35 \mathrm{~S}$ CaMV promoter, into eggplant (termed "event" EE-1) to control feeding damage by EFSB (Mahyco has had a long-term relationship with Monsanto in India for producing $\mathrm{Bt}$ cotton. Monsanto was recently acquired by Bayer). The crylA gene is widely used in Bt cotton and has a long history of safe use (ILSI CERA, 2010). Bt eggplant dem- 
onstrated control of EFSB in contained greenhouse trials in India. In late 2003, a partnership was formed between Mahyco, Cornell University, the United States Agency for International Development (USAID), and public sector partners in India, Bangladesh, and the Philippines under the Agricultural Biotechnology Support Project II (ABSPII) (Shelton et al. 2017). Mahyco donated the EE-1 event to the Bangladesh Agricultural Research Institute (BARI), and Mahyco incorporated it into BARI-developed local openpollinated $(\mathrm{OP})$ varieties (OP lines allow farmers to save seed; however, BARI discourages seed saving because of potential out-crossing, which would reduce the purity of the seed). BARI conducted confined field trials that demonstrated the $\mathrm{Bt}$ varieties provided excellent control of EFSB compared to non-Bt isolines (same variety but without the Bt gene) (Fig. 4). Results from trials conducted in Bangladesh were used to develop the regulatory dossier that was submitted to Bangladeshi authorities for cultivation (see below).

The ABSPII project ended in 2014. A new 3 -year cooperative agreement was awarded in 2015 under the USAID-funded Feed the Future South Asia Eggplant Improvement Partnership (bteggplant.cornell.edu). The main objectives were to scale up the improved Bt eggplant to Bangladeshi farmers, provide capacity building within the Bangladesh agricultural institutions, and work with the University of the PhilippinesLos Baños to develop, submit, and shepherd a regulatory dossier for the Philippines that meets international standards. This article only focuses on Bangladesh.

\section{THE INDIAN SITUATION}

Much of the early ABSPII work on Bt eggplant was centered in India, a country that produces nearly $25 \%$ of the world's eggplants, grown mostly by smallholder farmers on a total of 1.3 million acres but with relatively low production because of infestation by EFSB (Krishna and Qaim 2007). Beginning in 2004, Bt hybrids were tested in several states of India and performed well, leading Krishna and Qaim (2007) to write "several Bt hybrids have been tested in the field and are likely to be commercialized in the near future." Unlike OP lines, hybrids do not breed true the following year so new seed must be obtained yearly. However, farmers generally prefer hybrids because of their enhanced yield and quality.

After extensive field trials and safety evaluations by Indian regulatory bodies, Bt eggplant was ready to be commercialized in India. However, antibiotech organizations, primarily Greenpeace, had a different plan and for years fought against Bt eggplant in courts of law and in the court of public opinion. Greenpeace, the world's largest "environmental" organization, uses its considerable resources and influence to advocate for a zero-tolerance for GM crops (Davidson 2008; Shelton 2015) (www.activistfacts
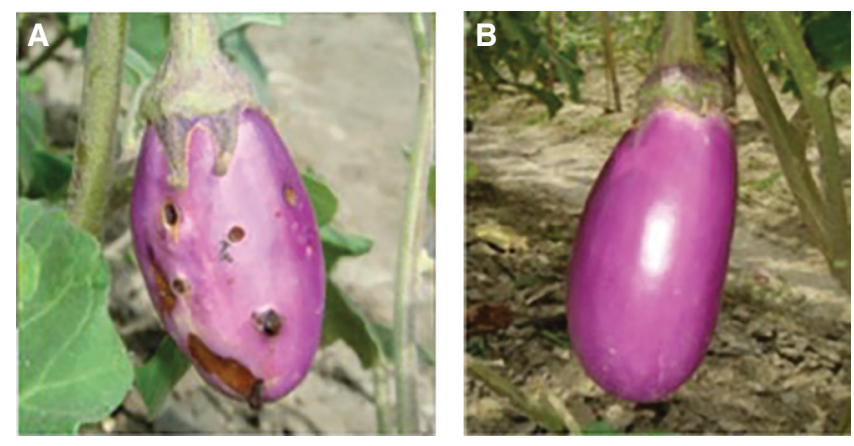

Figure 4. Comparison of Uttara brinjal variety showing injury by $(A)$ the eggplant fruit and shoot borer to non-Bt brinjal, and $(B)$ lack of injury in Bt brinjal. (Photograph provided by M.J. Hossain, Feed the Future South Asia Eggplant Improvement Partnership.) 
A.M. Shelton et al.

.com/organizations/131-greenpeace). Greenpeace spent millions to prevent Bt eggplant from coming to market in India, with a large amount used in legal costs (Shelton 2010). As a result, largely of antibiotech activists' efforts, the Indian Minister of the Environment and Forests, the last "gatekeeper" before Bt eggplant would be commercialized, decided to impose a moratorium on Bt eggplant on February 9, 2010, which remains today (Shelton 2010). India's neighbor, Bangladesh, which also produces eggplant, decided to move forward.

\section{Bt EGGPLANT BECOMES A REALITY IN BANGLADESH}

After successfully breeding EE-1 into nine local OP varieties, BARI applied to the National Technical Committee on Crop Biotechnology (NTCCB) for their release. Following the recommendation from the NTCCB, the application for release was forwarded to the National Committee on BioSafety. The Bangladesh government granted approval for release of four lines on October 30, 2013 (Fig. 5). On January 22, 2014, Bt eggplant seedlings were distributed to 20 farmers in four districts, making Bangladesh the first developing country to allow the commercial cultivation of a GE vegetable crop (Mondal 2018).

Bt brinjal was made available to growers for demonstration trials. In 2014-2015, BARI provided seeds or transplants to its On-Farm Research Division) to conduct research/demonstration trials on 108 farmer fields in 19 districts. In 2015-2016 and 2016-2017, demonstration trials were conducted in 250 farmer fields in 25 districts and 512 farmer fields in 36 districts, respectively. In 2017-2018, BARI provided seeds to 569 farmers in 40 districts. In addition to distribution by BARI, seeds were distributed to farmers through the Department of Agricultural Extension (DAE) to 6000 and 7001 farmers in 2016-2017 and 2017-2018, respectively, and for sale through the Bangladesh Agricultural Development Corporation (BADC) to an additional 17,950 farmers in 2018, making a total of 27,012 farmers in 2018 (Mondal 2018; Shelton et al. 2018). Fruit from these fields was sold in the market and readily purchased by consumers. Because the four lines are OP varieties, farmers can keep their seed (or give or sell it to others) so the actual number of farmers growing Bt brinjal is likely much higher than the statistics reported above.

The initial application for Bt brinjal included nine varieties that would accommodate regional preferences, but only four were approved in 2013. There are continuing efforts to release other varieties, especially ones that are resistant to bacterial wilt, a severe disease in Bangladesh.

\section{CONTROL OF EFSB AND EFFECTS ON NONTARGET ARTHROPODS IN BANGLADESH}

A 2-year experiment (2016-2017) conducted by BARI scientists compared the four Bt varieties to their isolines (same variety but without the $B t$ gene) with and without insecticide treatments (Prodhan et al. 2018). Results indicated that

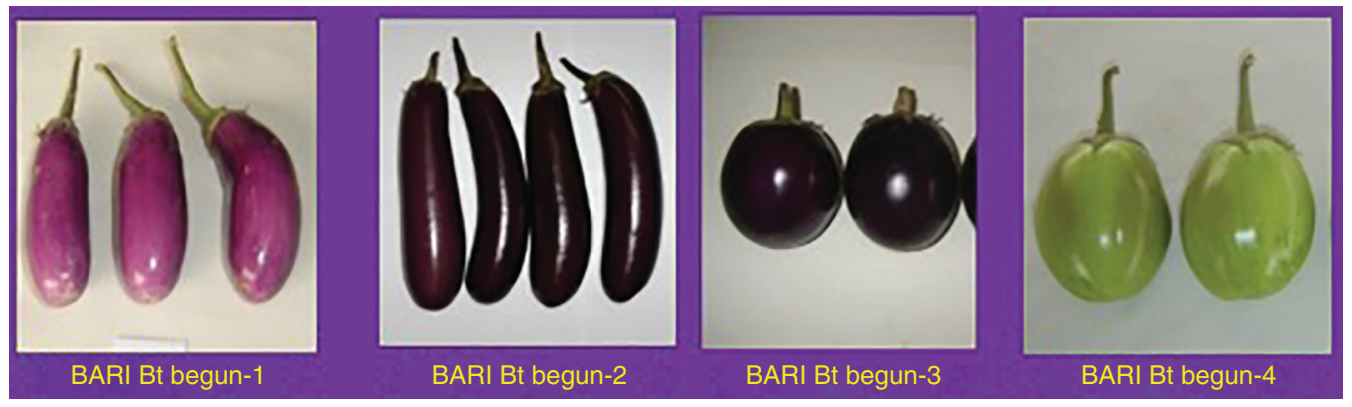

Figure 5. Four Bt brinjal lines currently commercialized in Bangladesh. (Photograph provided by M.J. Hossain, Feed the Future South Asia Eggplant Improvement Partnership.) 
the four Bt varieties had increased fruit production and minimal EFSB fruit infestation compared with their respective non-Bt isolines. Fruit infestation for $\mathrm{Bt}$ varieties varied from $0 \%$ to $2.27 \%$ in $2016,0 \%$ in 2017 , and was not significantly affected by the spray regime in either year. In contrast, fruit infestation in non-Bt lines reached $36.70 \%$ in 2016 and $45.51 \%$ in 2017, even with weekly spraying. It should also be noted that when a Bt fruit was classified as being infested, only a superficial blemish was seen and no live larvae were present.

Statistically similar densities of nontarget arthropods, including beneficial arthropods, were generally observed in both $\mathrm{Bt}$ and non-Bt varieties. An additional trial that focused on a single Bt variety and its isoline provided similar results on infestation levels, with and without sprays, and showed no significant effects on nontarget arthropods. These results are similar to studies conducted in the Philippines that demonstrated excellent control of EFSB (Hautea et al. 2016) and lack of effect on nontarget organisms (Navasero et al. 2016).

\section{ECONOMICS AND INSECTICIDE PATTERNS WHEN USING Bt BRINJAL}

In an ex ante (before the event) study on adoption of Bt eggplant in Bangladesh (Islam and Norton 2007), it was estimated that adoption of Bt eggplant would reduce insecticide use by $80 \%$ and increase the gross profit margin by nearly 45\%. Because Bt eggplant has been commercialized, these predictions can be compared to actual results. In a study conducted by BARI, scientists in 35 districts during the 2016-2017 cropping season using $505 \mathrm{Bt}$ brinjal farmers and 350 non-Bt brinjal farmers, net returns per hectare were $\$ 2151 /$ ha for Bt brinjal as compared to $\$ 357 /$ ha for non-Bt brinjal, a sixfold difference (Rashid et al. 2018). This study also indicated that farmers saved $61 \%$ of the pesticide cost compared to non-Bt brinjal farmers and experienced no losses because of EFSB. It is likely that pesticide reduction could be reduced further once farmers have more experience controlling EFSB with Bt eggplant, and thus economic returns would be even higher.
In the 2-year study conducted by Prodhan et al. (2018), an economic analysis revealed that all $\mathrm{Bt}$ lines had higher gross returns than their non-Bt isolines. The nonsprayed, non-Bt isolines resulted in negative returns in most cases. Maximum fruit yield was obtained from sprayed plots compared to nonsprayed plots, indicating that other insects such as whiteflies, thrips, and mites (these arthropods are not affected by CrylAc) can reduce plant vigor and subsequent fruit weight. Efforts are now underway to develop treatment guidelines for the complex of "sucking insects" that can reduce plant vigor.

\section{SUSTAINING THE TECHNOLOGY}

The long-term success of Bt brinjal in Bangladesh depends on many biological and administrative factors. Farmers depend on high quality seed so a major effort in the project has been to build capacity within BARI to ensure that quality seed-genetic purity, high viability, and expression of CrylAc-is produced in adequate amounts to meet grower demand. To accomplish this, the project has undertaken capacity building efforts to train BARI scientists following the model of "Excellence Through Stewardship," a life-cycle approach to GE product management (www.excellencethroughstewardship.org).

Likewise, farmers are being trained on the unique aspects of Bt brinjal, mainly the requirements to plant a refuge of non-Bt brinjal as border rows and the need to manage other "sucking insects." A refuge is required as a strategy to delay the evolution of resistance by EFSB to the Cry1Ac protein (Bates et al. 2005). Research has demonstrated that utilizing a refuge is vital for ensuring the durability of Bt technology (Tang et al. 2001). Therefore, monitoring farmer adoption of and compliance with refuge-planting strategies is essential. Monitoring compliance of farmers who save or distribute their saved seed is even more challenging. Recent reports have highlighted the difficulty in monitoring the planting of refuges in developing countries (India and Brazil) compared to Australia and the United States (Carrière et al. 2019). An alternative to planting separate refuges is to mix Bt seeds with a proportion of non-Bt seeds 
A.M. Shelton et al.

in the same bag sold to growers, a strategy called "refuge in the bag" (RIB). While the RIB strategy essentially forces farmers to plant a refuge, it is most suitable for insects that have limited movement between plants in the larval stage (Tang et al. 2001). Additional research is needed to determine whether the RIB strategy will be suitable for EFSB.

There is general agreement (Bates et al. 2005) and experimental evidence (Zhao et al. 2003) that plants expressing multiple Bt proteins will be more durable for control of an insect pest. Thus, efforts should be focused on introducing eggplant varieties with multiple Bt genes, as soon as possible. Mahyco has developed a twogene $\mathrm{Bt}$ event and there are discussions underway about having access to it. Meanwhile, studies have been completed to assess the baseline susceptibility of populations of EFSB to the CrylAc expressed in Bt eggplants, so any changes in susceptibility over time can be determined, and appropriate measures taken. It should also be noted that the four Bt varieties currently used are not suitable for the summer season, a time when populations of EFSB are at their highest. Fortuitously, this Bt crop-free period acts as another component of a resistance management strategy. Other management strategies that are compatible with Bt plants are being considered, including removing infested plants, using pheromone disruption, enhancing biological control, and using more selective insecticides. However, farmers are typically less willing to adopt such practices because of their increased labor and costs, compared to using $\mathrm{Bt}$ plants (Shelton 2007).

\section{COMMUNICATING ABOUT Bt BRINJAL}

Although the BARI-USAID-Cornell-Sathguru project focuses on Bt brinjal, it serves a larger role because it is the first GE food crop to be released and widely adopted by farmers and consumers in a developing country. Thus, it has been in the spotlight globally for the last 5 years. This project includes communication efforts that focus on two major activities: (1) improved information sharing internally and externally to promote science-based public awareness of GE crops; and (2) support communications, outreach, and knowledge sharing by farmers, extension personnel, community organizations, and communication practitioners. An important communication avenue is the project's website (Bteggplant.cornell.edu), which serves as the face of the project. This site is actively maintained and contains print and audiovisual materials for information sharing and awareness building. The project has developed a strong social media presence on twitter (@Bt_eggplant) and through various blogs. Currently, more than 4500 people follow posts and updates through the Cornell Alliance for Science. Factual news from national and international articles are shared and comments and feedback are monitored and responded to when suitable. The website also contains several videos, including two produced by BARI, highlighting the success of $\mathrm{Bt}$ brinjal in the field and endorsement by local farmers.

The project also works closely with the Cornell Alliance for Science (allianceforscience .cornell.edu), which provides factual information about agricultural biotechnology. The Alliance has enhanced capacity in social media that benefits the project in the short and long term. The Alliance is leading efforts to expand biotechnology communication activities in Bangladesh to include other GE crops, for example, lateblight-resistant potatoes and nutritionally enhanced rice. A new comprehensive communication initiative funded by the Bill \& Melinda Gates Foundation-Farming Future Bangladesh-has been formed to create an empowered community of advocates to develop a sustainable enabling environment for biotechnology in Bangladesh.

\section{WHY IS THE BANGLADESH Bt EGGPLANT PROJECT SUCCEEDING?}

ABSPII was essential to the success of the Bangladesh Bt eggplant project because it identified a strong need for the project, was well-supported financially and programmatically by USAID, utilized effective partners in India (Sathguru), Bangladesh (BARI), and the United States (Cornell), and had the good fortune to have event EE-1 generously donated by Mahyco. When 
ABSPII ended, the project continued with support from USAID's Feed the Future program started in 2015. In addition to these enabling factors, it is essential to acknowledge that the project has received political support from key Bangladeshi people since its inception. In contrast to India where the project stopped because of political pressure from well-funded groups opposed to biotechnology, Bangladesh received strong support from the Bangladeshi Government, especially Prime Minister Sheikh Hasina and the Honorable Agriculture Minister Begum Matia Chowdhury, MP. Chowdhury's words from a Bt brinjal workshop held in March 2017 in Bangladesh made the government's position clear:

Development of brinjal fruit and shoot insect resistant-Bt brinjal is a success story of local and foreign collaboration. We will be guided by the science-based information, not by the nonscientific whispering of a section of people. Good science will move on its own course keeping the anti-science people down. As human beings, it is our moral obligation that all people in our country should get food and not go to bed on an empty stomach. Biotechnology can play an important role in this effort.

In January 2019, Begum Matia Chowdhury was replaced as the Agriculture Minister by Dr. M. Abdul Razzaque, a well-respected agricultur- al scientist. At the time this article was written, efforts are underway to brief Dr. Razzaque in more detail on the project and advocate for his support.

\section{SECURING THE FUTURE OF Bt BRINJAL IN BANGLADESH}

The benefits of Bt brinjal are clear: increased yield and economic return to farmers, decreased risk to humans and the environment, and sustainable production. Farmers are pleased with the performance of Bt brinjal (Fig. 6). The experiences by farmers who have used Bt brinjal have led to an increased demand for the seed, not only for the four current Bt lines but also for additional Bt lines that would be suitable to other regions or markets in Bangladesh. The question is whether the demand can be met by the current system in which BARI is the sole producer of Bt brinjal breeder seed, and BADC increases the seed and sells it through their traditional channels. So far, the private sector has not been allowed to produce Bt brinjal for distribution in Bangladesh, although the lines grown originated from the private sector's (Mahyco) donated event, EE-1. The government acknowledges that the private sector should be a player in the future but has been hesitant to allow them to produce $\mathrm{Bt}$ brinjal for the time

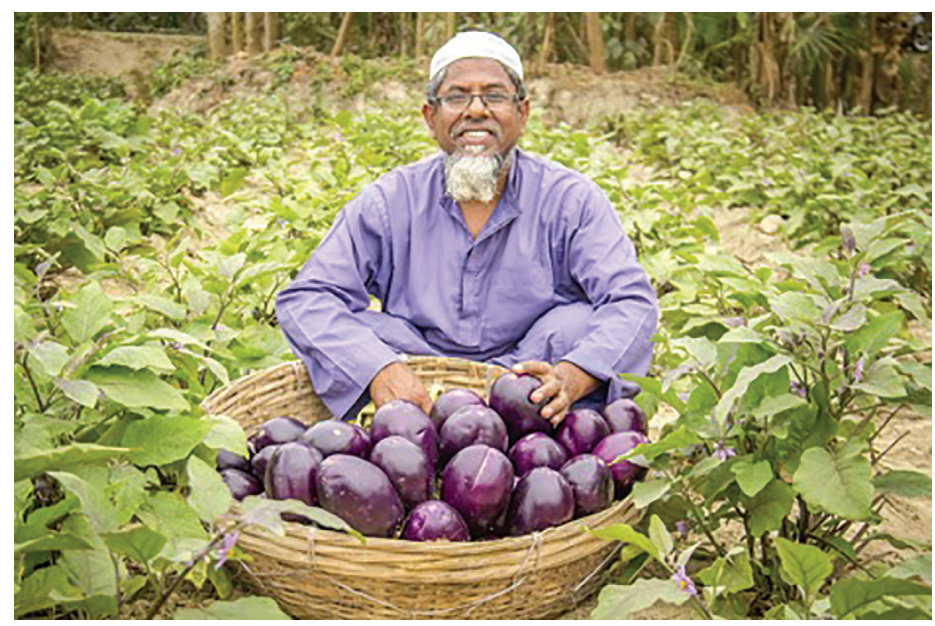

Figure 6. Bangladeshi Bt brinjal farmer, Shahajahan Ali, with harvested Bt brinjal. (Photograph from the personal collection of Md. Arif Hossain.) 
A.M. Shelton et al.

being. Meanwhile, there are ongoing discussions about allowing the private sector to complement the existing efforts of the government by producing their own hybrids.

In all but a few instances (e.g., virus-resistant papaya), it has been the private sector that spent the effort and considerable resources needed to develop a transformed line ("event"), spent millions on the regulatory process to have it approved, developed varieties suitable for the location, distributed seeds to farmers, and provided stewardship practices (e.g., technology and communication) to enhance the product's future. Bangladesh has had considerable assistance from the outside (Mahyco, Cornell, USAID) to get to the point where more than 27,000 rural farmers are producing Bt brinjal and selling it in the local markets or to brokers who distribute to urban consumers.

Continued funding from the outside is uncertain so the Bangladesh government will have to take more responsibility for the future of $\mathrm{Bt}$ brinjal. Our project has focused on capacity building to help Bangladesh take on the various tasks needed for successful seed production, distribution, cultivation, adoption, and refugemonitoring of Bt brinjal. At the same time, we are promoting conversations between the Bangladeshi Government and the private sector to help coordinate the various activities needed.

There are certainly challenges ahead for the continued success of Bt brinjal in Bangladesh. However, these challenges can be met with a detailed strategic plan that ensures cooperation of Bangladeshi agencies and adequate resources for Bt brinjal. Such planning will also reap benefits as other biotech crops are being developed in Bangladesh for the future. The private seed sector should play a critical role in such plans.

\section{THE ROLE OF THE PRIVATE SECTOR IN BANGLADESH}

The seed sector in Bangladesh is changing. Though most plant breeding in Bangladesh continues to be in the public domain, private companies are becoming increasingly involved in plant breeding in response to the growing demand from farmers for good-quality and better- performing varieties. Major, private-sector seed companies in Bangladesh include Supreme seeds, Lal Teer seeds, ACI seeds, GETCO, and others, and NGO-operated seed enterprises, including the Bangladesh Rural Advancement Committee (BRAC), PROSHIKA, Grameen Krishi Foundation, Rangpur Dinajpur Rural Service (RDRS), and others. These players are involved in trials of imported varieties of vegetables and potatoes, development of improved varieties of indigenous vegetables through selection and screening, development of hybrid vegetables and maize, and seed production and marketing. They also produce hybrid seeds of rice and maize using imported parent lines. The private sector contributes in technology dissemination and the education of farmers and traders throughout the country. They have built strong marketing networks throughout the country. Private seed companies play major roles in importing rice hybrids, seed potatoes, jute seeds, maize hybrids, and winter vegetable seeds where the public sector is generally inactive as a matter of policy.

Currently, in the private sector there are more than 300 companies along with over 22,000 registered seed dealers operating across Bangladesh. They have a strong seed marketing network throughout the country and strong commitment to enhance their involvement in this sector. Moreover, the growing engagements of the private sector seed companies have resulted in the engagement of thousands of contract farmers in the formal seed production chain, leading to improved livelihoods for rural communities. USAID strongly believes in the importance of the private sector becoming more involved in Bt brinjal seed production. The Seed Wing of the Ministry of Agriculture and several donor-assisted projects have been acting as catalysts for building the capacity of the private sector to play a greater role and take responsibility for achieving the seed policy goal of making quality seed available in timely ways to the farmers of Bangladesh in cost-effective ways. The private sector has been provided with adequate representation in all bodies established by the government for administering the seed industry where the public/private/NGO sectors 
can discuss issues for the balanced and sustainable growth of the seed sector.

With diminished resources available in the public sector over the last three decades, the private seed sector in Bangladesh has shown significant development and expansion. Achieving an ideal partitioning of seed sector roles among private and public sectors under Bangladesh agro-socio-economic conditions is not easy given that the buying capacity of the farmers is limited and the government's food security goals entail availability of quality seed at an affordable price. However, finding a balance will ensure that safe and effective GE technologies will reach resource-poor farmers in Bangladesh.

\section{REPLICATING THE BANGLADESHI PROJECT}

The results seen in Bangladesh demonstrate that Bt eggplant will result in economic benefits for farmers and dramatically reduce health risks to humans and the environment. Can this success be replicated in other Asian countries where EFSB ravages eggplants, especially in fields grown by resource-poor farmers? Certainly, GE technology is available but it was available in India before it was commercialized in Bangladesh. History has shown that these two neighboring countries approached Bt eggplant differently, with Bangladeshi leaders displaying the courage to move forward based on the clear need to help farmers reduce applications of chemical sprays. In contrast, in spite of the similar needs of farmers in India and the recommendations of Indian scientists and regulators that Bt brinjal is safe and effective, the Indian Minister of the Environment and Forests imposed a moratorium on commercialization of Bt eggplant that remains today (Shelton 2010). It appears that the Indian minister based his decision not on science or farmers' need but instead on political pressure from groups against GE crops. The consequence is that farmers in India continue to rely on chemical-based insecticide management practices to reduce damage by EFSB. Yet such a strategy is often ineffective, whereas Bt brinjal provides excellent control with minimal need for sprays for other pests (Prodhan et al. 2018).
In India, the intense use of pesticides on vegetables and other crops causes severe hazards to farmers, consumers, and the environment (Grewal et al. 2017), but alternatives are available. Bt cotton became available in India in 2002 and remains the only GM product available to Indian farmers. Use of Bt cotton over a 10-year period resulted in farmers reducing their pesticide use by at least $50 \%$ with the largest reductions of $70 \%$ occurring with the most toxic types of chemicals (Kouser and Qaim 2011). This helped avoid at least 2.4 million cases of pesticide poisoning, saving at least US\$14 million in annual benefit costs. Could the same types of benefits occur in India if it were allowed to be grown in India, as it presently is in Bangladesh?

Time will tell whether Bt eggplant and other useful products of biotechnology will become available to benefit farmers, consumers, and the environment in other countries, or will fear and misinformation impede their development and use? For the time being, Bt eggplant in Bangladesh serves as a celebrated example of the successes that can be achieved.

\section{ACKNOWLEDGMENTS}

The success of this project is the result of many organizations and people, including the Maharashtra Hybrid Seed Company (Mahyco) that created the Bt eggplant "event" and incorporated it into varieties used in Bangladesh, and who continue to provide important advice for the project; the vision and support of the Government of Bangladesh; the Bangladesh Agricultural Research Institute (BARI) and its associated agencies, including the Department of Agricultural Extension (DAE) and the Bangladesh Agricultural Development Corporation (BADC); funding and advice provided by the United States Agency for International Development (USAID); personnel in Cornell's College of Agriculture and Life Sciences International Programs (CALS-IP) who managed the Agricultural Biotechnology Support Project II (ABSPII) and now manage the Feed the Future South Asia Eggplant Improvement Partnership; Sathguru Management Consultants Pvt. Ltd.; and the Cornell Alliance for Science. Without these 
A.M. Shelton et al.

partners, the project would not have been able to have the impact it has had.

\section{REFERENCES}

Ali MI, Ali MS, Rahman MS. 1980. Field evaluation of wilt disease and shoot and fruit borer attack of different cultivars of brinjal. Bangladesh J Agric Sci 7: 193-194.

Bangladesh Bureau of Statistics. 2018. Yearbook of Agricultural Statistics-2017, Bangladesh Bureau of Statistics (BBS) Statistics and Informatics Division (SID) Ministry of Planning Government of the People's Republic of Bangladesh. www.bbs.gov.bd

Bates SL, Zhao JZ, Roush RT, Shelton AM. 2005. Insect resistance management in GM crops: Past, present and future. Nat Biotechnol 23: 57-62. doi:10.1038/nbt1056

Brookes G, Barfoot P. 2017. GM crops: Global socio-economic and environmental impacts 1996-2015. PG Economics Ltd., Dorchester, UK.

Carrière Y, Brown ZS, Downes SJ, Gujar G, Epstein G, Omoto C, Storer NP, Mota-Sanchez D, Jorgensen PS, Carroll SP. 2019. Governing evolution: A socioecological comparison of resistance management for insecticidal transgenic Bt crops among countries. Ambio doi:10 .1007/s13280-019-01167-0

Davidson S. 2008. Forbidden fruit: Transgenic papaya in Thailand. Plant Physiol 147: 487-493. doi:10.1104/pp .108 .116913

Del Prado-Lu J. 2015. Insecticide residues in soil, water, and eggplant fruits and farmers' health effects due to exposure to pesticides. Environ Health Prev Med 20: 53-62. doi:10 $.1007 / \mathrm{s} 12199-014-0425-3$

Fischhoff DA, Bowdishi KS, Perlak FJ, Marrone PG, McCormick SM, Niedermeyer JG, Dean DA, Kusano-Kretzmer K, Mayer EJ, Rochester DE, et al. 1987. Insect tolerant transgenic tomato plants. Nat Biotechnol 5: 807-813. doi:10.1038/nbt0887-807

Grewal AS, Singlal A, Kamboj P, Dua JS. 2017. Pesticide residues in food grains, vegetables and fruits: A hazard to human health. J Med Chem Toxicol 2: 40-46. doi:10 $.15436 / 2575-808 x .17 .1355$

Hautea DM, Taylor LD, Masanga APL, Sison MLJ, Narciso JO, Quilloy RB, Hautea RA, Shotkoski FA, Shelton AM. 2016. Field performance of Bt eggplants (Solanum melongena L.) in the Philippines: CrylAc expression and control of the eggplant fruit and shoot borer (Leucinodes orbonalis Guenée). PLoS ONE 11: e0157498. doi:10 .1371/journal.pone.0157498

Heckel D. 2012. Learning the ABCs of Bt: ABC transporters and insect resistance to Bacillus thuringiensis provide clues to a crucial step in toxin mode of action. Pestic Biochem Physiol 104: 103-110. doi:10.1016/j.pestbp.2012.05.007

ILSI CERA. 2010. A review of the environmental safety of the CrylAc protein. ILSI CERA, Washington, DC.

Islam SMF, Norton GW. 2007. Bt eggplant for fruit and shoot borer resistance in Bangladesh. In Economic and environmental benefits and costs of transgenic crops: Exante assessment (ed. Ramasamy C, Selvaraj KN, Norton GW, Vijayaraghavan K), pp. 91-106. Tamil Nadu Agricultural University, Coimbatore, India.
James C. 2000. Global status of commercialized transgenic crops: 2000. ISAAA Briefs, No. 21. ISAAA, Ithaca, NY.

James C. 2018. Global status of commercialized biotech/GM crops: 2017. ISAAA Briefs, No. 53. ISAAA, Ithaca, NY.

Kennedy GG. 2008. Integration of insect-resistant genetically modified crops within IPM programs. In Integration of insect-resistant genetically modified crops within IPM programs (ed. Romeis J, Shelton A, Kennedy G), pp. 1-26. Springer Science+Business Media, New York.

Kouser S, Qaim M. 2011. Impact of Bt cotton on pesticide poisoning in smallholder agriculture: A panel data analysis. Ecol Econ 70: 2105-2113. doi:10.1016/j.ecolecon .2011.06.008

Krishna VV, Qaim M. 2007. Potential socieoeconomic impacts of Bt eggplant in India. In Economic and environmental benefits and costs of transgenic crops: Ex-ante assessment (ed. Ramasamy C, et al.), pp. 57-71. Tamil Nadu Agricultural University, Coimbatore, India.

Mondal MRI. 2018. Success on Bt brinjal in Bangladesh. Asia-Pacific Consortium on Agricultural Biotechnology and Bioresources Asia-Pacific Association of Agricultural Research Institutions. Bangkok, Thailand.

Naranjo SE, Ellsworth PC. 2009. Fifty years of the integrated control concept: Moving the model and implementation forward in Arizona. Pest Manag Sci 65: 1267-1286. doi:10 $.1002 /$ ps. 1861

Navasero MV, Candano RN, Hautea D, Hautea RA, Shotkoski FA, Shelton AM. 2016. Assessing potential impact of Bt eggplants on non-target arthropods in the Philippines. PLOS ONE 11: e0165190. doi:10.1371/journal.pone .165190

Prodhan MZH, Hasan MT, Chowdhury MMI, Alam MS, Rahman ML, Azad AK, Hossain MJ, Naranjo SE, Shelton AM. 2018. Bt Eggplant (Solanum melongena L.) in Bangladesh: Fruit production and control of eggplant fruit and shoot borer (Leucinodes orbonalis Guenee), effects on non-target arthropods and economic returns. PLoS ONE 13: e0205713. doi:10.1371/journal.pone.0205713

Rashid MA, Hasan MK, Matin MA. 2018. Socio-economic performance of Bt eggplant cultivation in Bangladesh. Bangladesh J Agric Res 43: 187-203. doi:10.3329/bjar .v43i2.37313

Romeis J, Shelton AM, Kennedy GG. 2008. Integration of insect-resistant genetically modified crops within IPM programs, 441 pp. Springer, Dordrecht, Netherlands.

Romeis J, Naranjo SE, Meissle M, Shelton AM. 2019. Genetically engineered crops help support conservation biological control. Biol Control 130: 136-154. doi:10.1016/j .biocontrol.2018.10.001

Shelton AM. 2007. Considerations on the use of transgenic crops for insect control. J Dev Stud 43: 890-900. doi:10 $.1080 / 00220380701384562$

Shelton AM. 2010. The long road to commercialization of Bt brinjal (eggplant) in India. Crop Prot 29: 412-414. doi:10 .1016/j.cropro.2010.02.016

Shelton AM. 2012. Genetically engineered vegetables expressing proteins from Bacillus thuringiensis for insect resistance: Successes, disappointments, challenges and ways to move forward. GM Crops Food 3: 175-183. doi:10.4161/gmcr.19762 
Shelton AM. 2015. Tragic papaya: 12-part series. anthonymshelton.com/tragicpapaya

Shelton AM, Zhao JZ, Roush RT. 2002. Economic, ecological, food safety and social consequences of the deployment of Bt transgenic plants. Annu Rev Entomol 47: 845881. doi:10.1146/annurev.ento.47.091201.145309

Shelton AM, Olmstead DL, Burkness EC, Hutchison WD, Dively G, Welty C, Sparks AN. 2013. Multi-state trials of Bt sweet corn varieties for control of the corn earworm (Lepidoptera: Noctuidae). J Econ Entomol 106: 21512159. doi:10.1603/EC13146

Shelton AM, Hokanson KE, Hautea DM, Hossain MJ, Hossain MA, Paranjape V, Hautea RA, McCandless L, Sarwer SH. 2017. Bt eggplant: A genetically engineered "minor" crop comes of age in Bangladesh and the Philippines. ISB News Report, August.

Shelton AM, Hossain MJ, Paranjape V, Azad AK, Raham ML, Khan ASMMR, Prodhan MZH, Rashid MA, Majumder R, Hossain MA, et al. 2018. Bt eggplant project in Bangladesh: History, present status, and future direction. Front Bioeng Biotechnol 6: 106. doi:10.3389/fbioe .2018 .00106
Shirale D, Patil M, Parimi S. 2017. Insecticide resistance in field populations of Leucinodes orbonalis (Lepidoptera: Crambidae) in India. Can Entomol 149: 399-407. doi:10.4039/tce.2017.3

Smith CM, Clement SL. 2012. Molecular bases of plant resistance to arthropods. Annu Rev Entomol 57: 309 328.

Stern V, Smith R, Van den Bosch R, Hagen K. 1959. The integration of chemical and biological control of the spotted alfalfa aphid: The integrated control concept. Hilgardia 29: 81-101. doi:10.3733/hilg.v29n02p081

Tang JD, Collins HL, Metz TD, Earle ED, Zhao J, Roush RT, Shelton AM. 2001. Greenhouse tests on resistance management of Bt transgenic plants using refuge strategies. $J$ Econ Entomol 94: 240-247. doi:10.1603/0022-0493-94.1 .240

Zhao J, Cao J, Li Y, Collins HL, Roush RT, Earle ED, Shelton AM. 2003. Plants expressing two Bacillus thuringiensis toxins delay insect resistance compared to single toxins used sequentially or in a mosaic. Nat Biotechnol 21: 1493 1497. doi:10.1038/nbt907 


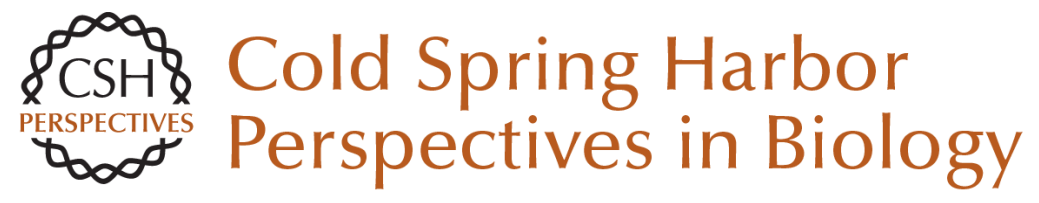

\section{Bt Brinjal in Bangladesh: The First Genetically Engineered Food Crop in a Developing Country}

Anthony M. Shelton, Md. J. Hossain, Vijay Paranjape, Md. Z.H. Prodhan, Abul K. Azad, Rituparna Majumder, Sayed H. Sarwer and Md. A. Hossain

Cold Spring Harb Perspect Biol 2019; doi: 10.1101/cshperspect.a034678 originally published online June 10, 2019

\section{Subject Collection Engineering Plants for Agriculture}

Plant Inflorescence Architecture: The Formation, Activity, and Fate of Axillary Meristems Yang Zhu and Doris Wagner

Sub1 Rice: Engineering Rice for Climate Change Kyle Emerick and Pamela C. Ronald

Engineering Disease-Resistant Cassava Z.J. Daniel Lin, Nigel J. Taylor and Rebecca Bart

Many Facets of Dynamic Plasticity in Plants Xiaodong Yang and Sally A. Mackenzie

How Do Strigolactones Ameliorate Nutrient Deficiencies in Plants? Kaori Yoneyama

Mechanisms and Impact of Symbiotic Phosphate Acquisition Chai Hao Chiu and Uta Paszkowski
The Sweet Side of Plant-Specialized Metabolism Thomas Louveau and Anne Osbourn

The Role of Dwarfing Traits in Historical and Modern Agriculture with a Focus on Rice Angel Ferrero-Serrano, Christian Cantos and Sarah M. Assmann

Bt Brinjal in Bangladesh: The First Genetically

Engineered Food Crop in a Developing Country Anthony M. Shelton, Md. J. Hossain, Vijay Paranjape, et al.

Circadian Rhythms in Plants Nicky Creux and Stacey Harmer

Developing Blight-Tolerant American Chestnut

Trees William A. Powell, Andrew E. Newhouse and Vernon Coffey

Stomatal Development and Perspectives toward Agricultural Improvement Hitoshi Endo and Keiko U. Torii

For additional articles in this collection, see http://cshperspectives.cshlp.org/cgi/collection/

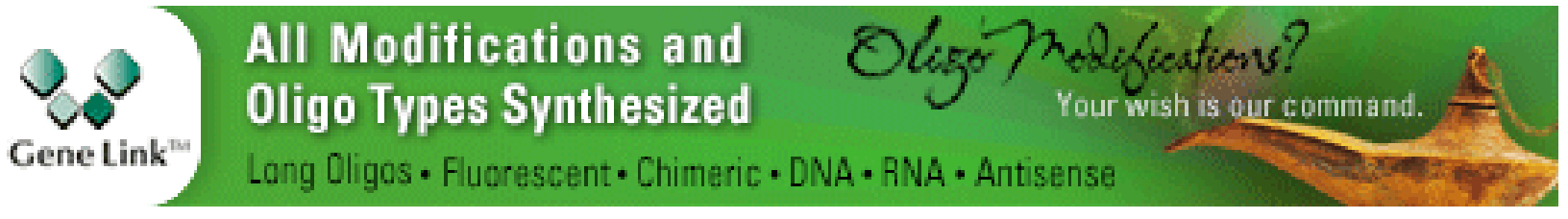

